\title{
Activin Receptor Type-2B
}

National Cancer Institute

\section{Source}

National Cancer Institute. Activin Receptor Type-2B. NCI Thesaurus. Code C21274.

Activin receptor type-2B (512 aa, $\sim 58 \mathrm{kDa}$ ) is encoded by the human ACVR2B gene. This protein plays a role in protein kinase-dependent signaling and embryonic development. 